

IZA DP No. 366

Research and Policy Issues in High-Skilled International Migration:

A Perspective with Data from the United States

Mark C. Regets

September 2001 


\title{
Research and Policy Issues in High-Skilled International Migration: A Perspective with Data from the United States
}

\author{
Mark C. Regets \\ National Science Foundation, Arlington and IZA, Bonn
}

Discussion Paper No. 366
September 2001

IZA

P.O. Box 7240

D-53072 Bonn

Germany

Tel.: +49-228-3894-0

Fax: +49-228-3894-210

Email: iza@iza.org

This Discussion Paper is issued within the framework of IZA's research areas Mobility and Flexibility of Labor Markets and The Future of Work. Any opinions expressed here are those of the author(s) and not those of the institute. Research disseminated by IZA may include views on policy, but the institute itself takes no institutional policy positions.

The Institute for the Study of Labor (IZA) in Bonn is a local and virtual international research center and a place of communication between science, politics and business. IZA is an independent, nonprofit limited liability company (Gesellschaft mit beschränkter Haftung) supported by the Deutsche Post AG. The center is associated with the University of Bonn and offers a stimulating research environment through its research networks, research support, and visitors and doctoral programs. IZA engages in (i) original and internationally competitive research in all fields of labor economics, (ii) development of policy concepts, and (iii) dissemination of research results and concepts to the interested public. The current research program deals with (1) mobility and flexibility of labor markets, (2) internationalization of labor markets and European integration, (3) the welfare state and labor markets, (4) labor markets in transition, (5) the future of work, (6) project evaluation and (7) general labor economics.

IZA Discussion Papers often represent preliminary work and are circulated to encourage discussion. Citation of such a paper should account for its provisional character. 
IZA Discussion Paper No. 366

September 2001

\section{ABSTRACT}

\section{Resarch and Policy Issues in High-Skilled International Migration: A Perspective with Data from the United States}

Highly-skilled migrants are becoming a more important part of the world economy and of policy debates in a diverse set of countries. The proliferation of skills around the world, increases in world trade, the growth of R\&D, and the general increase in the labor market demand for diverse sets of skills, have all contributed to the emergence of high-skilled migration as a major issue. High-skilled migration is often discussed in narrow terms of "brain drain/brain gain", when both the pattern of migration and its effects appear to be much more complex. However, our understanding of the effects of high skilled migration is much less than for international migration in general, and is based upon much less research and data. This paper reviews the possible effects of high skilled international migration, and the major research and policy questions that need answering.

JEL Classification: F22, J21, J24, J44, J16, F02

Keywords: $\quad$ Migration, skilled labor, doctorate, brain drain

Mark C. Regets

National Science Foundation

4201 Wilson Blvs., Room 965

Arlington, VA 22182

Tel.:+1-703-292-7813

Fax:+1-703-292-9092

Email: mregets@nsf.gov, MarkRegets@aol.com 


\section{Introduction}

Migration across national borders provokes many spirited political and policy debates. Although these debates are often most contentious when they deal with lower-skilled migrants, high-skilled migration also raises strong emotions. If nothing else, immigration of any sort changes the status quo. If lower-skilled migrants are sometimes said to take jobs that natives do not want, high-skilled migrants are usually employed in the types of jobs that many would prefer go to natives. At the same time, government in both less-developed and many developed countries worry about losing their more highly educated workers. As high-skilled migration appears to become more important to the world economy, it becomes all the more important to understand its likely effects. Unfortunately, these effects have not been well studied or measured and are likely to be more complex than acknowledged in most policy discussions.

This paper seeks to provide an overview of the major research and policy issues in the international migration of highly skilled individuals and their families. Knowledge and understanding of the effects of this migration are limited not only by available data (as is the case in much immigration research), but also by unanswered questions in labor market theory and economic growth theory: How fungible are skills among those with specialized knowledge? Does the presence in an economy of highly skilled workers affect investment and R\&D decisions by firms (increasing demand over time for high-skilled workers)? Do more scientists lead to more knowledge? This paper 
does not answer these questions, but deals with how these and other questions affect our understanding of high-skilled migration.

As the world largest economy, as the largest educator of foreign students and as a traditional nation of immigration, the United States is an important nexus for the international movement of high-skilled workers. As such, this paper uses US data on high-skilled migration to and from the United States to provide some insights into the magnitude and direction of some of the possible effects of high-skilled migration.

While this paper often focuses on economic and knowledge creation effects for individual countries and the global economy, it is also important to recognize that this should not be the only component of policy making on any form of immigration policy. Freedom of movement is highly valued as a human right, and is recognized as such in the Universal Declaration of Human Rights, albeit in a limited form. ${ }^{1}$ Aside from the maximization of human liberty, it seems likely that migrants themselves incur the greater economic benefits and costs of high-skilled migration - theory would suggest that at least the expected value of individual net benefits is positive for those who choose to migrate, although these benefits and costs may also include substantial non-economic factors. On the other hand, countries may seek to limit immigration for cultural reasons, or prefer for humanitarian reasons to favor immigration of family members of previous migrants. ${ }^{2}$

1. The UDHR calls for freedom of movement within national borders, and freedom of movement to leave any country.

2. In the United States, most permanent visas are issued to immigrants on the basis of family ties. Immigration and Naturalization Service records indicate that from 1993 to 1996, slightly 


\section{National and global consequences of high-skilled migration}

Table 1 outlines one attempt to lay out likely or possible economic effects of high-skilled international migration. This needs to include possible positive and negative economic effects for both receiving and sending countries. In additional to country-level effects, there are also global effects on the growth of technology and knowledge that cannot be easily assigned to individual polities.

The categories, "receiving" and "sending" are not meant be synonymous with "developed" and "less developed". Many developed countries, such as the United Kingdom, have expressed concerns about retaining their researchers, and many lessdeveloped countries do attract foreign talent in areas where they are able to offer opportunities to study or use unique geological and biological natural resources. Indeed, many countries may be both net receivers and net senders in different skill areas.

Few of the possible effects discussed in this paper are well established empirically, although some "indicator" data do exist. Thus, this most of all represents an agenda for research.

more than half of those granted permanent visas ("green cards") used family-based admission categories. 
Table 1. Possible global and national effects of high-skilled international migration

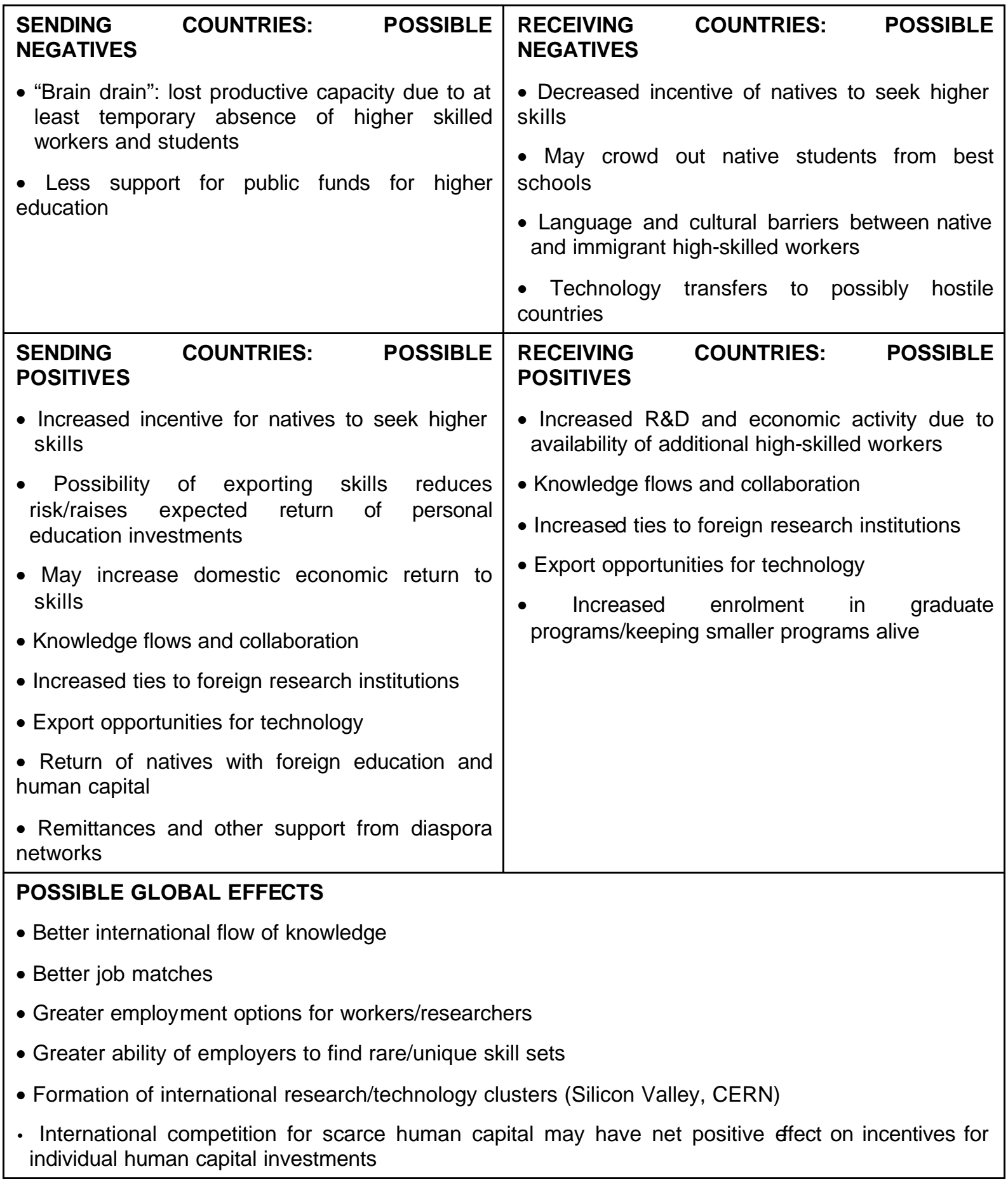




\section{Negative effects for sending countries}

A loss of productive capacity due to the, at least temporary, loss of highly skilled workers and students is the most discussed negative effect of high-skilled migration on sending countries. This "brain drain" has been an issue not just for countries, but for any area whose educated natives migrate - in the United States, rural states often worry about the products of their state universities moving to other parts of the United States where their skills are in greater demand. In addition to the direct effect on the availability of high-skilled labor, another consequence of highly educated workers leaving a country may be a reduction in political support for funding for higher education.

Table 2. Share of US foreign-born with foreign degrees

\begin{tabular}{|c|c|c|c|}
\hline & $\begin{array}{l}\% \text { with highest degree } \\
\text { from foreign school }\end{array}$ & $\begin{array}{l}\text { \% with any foreign } \\
\text { degree }\end{array}$ & $\begin{array}{l}\% \text { with foreign } \\
\text { secondary school }\end{array}$ \\
\hline Bachelor's degree & 49.1 & 51.1 & 67.4 \\
\hline Master's degree & 24.1 & 57.2 & 76.4 \\
\hline Professional degree & 60.0 & 69.3 & 74.3 \\
\hline $\mathrm{PhD}$ & 31.2 & 73.3 & 86.7 \\
\hline All degree levels & 40.2 & 54.7 & 71.0 \\
\hline
\end{tabular}

Source: NSF/SRS 1993 National Survey of College Graduates.

College educated migrants to the United States do have a significant proportion of their formal education from outside the United States. As shown in Table 2, about $55 \%$ of the college-educated foreign-born in $1993^{3}$ had at least one post-secondary

3. The 1993 National Survey of College Graduates, with over 150000 observations, is a National Science Foundation survey which provides a valid national sample of college graduates up to age 75 who were in the United States at the time of the 1990 Census and in April 1993. 
degree from an institution outside the United States, and $40 \%$ had their highest degree (or most recent if at the same degree level) from a foreign institution. Even at the highest education level, nearly one-third of the foreign-born with doctorates who were resident in the United States received their doctorates from foreign institutions. Although many immigrants to the United States arrive as children, $71 \%$ of the collegeeducated foreign-born graduated from a foreign secondary school, with their preuniversity education funded outside the United States.

Many countries are concerned with the return rates of their nationals who go to other countries for graduate training. Finn (1999) shows that slightly over half (53\%) of 1992-93 recipients of science and engineering doctorates from US schools were working in the United States in 1997.

\section{Positive effects for sending countries}

Less often discussed are the positive effects that may exist for countries whose highly skilled natives and citizens move across borders. In part, this is because of measurement difficulties. Although data on international migration is often poor, ${ }^{4}$ counts of initial migrations of people are easier to obtain than data on return migration or return knowledge flows. Nevertheless, there are several indicators that such benefits might exist. While there is talk of "brain drain", others have talked of "brain gain" or "brain circulation" to describe some of these complex effects.

4. The data limitations in the United States are possibly most succinctly illustrated through the title of a National Academy of Sciences study: Immigration Statistics: A Story of Neglect. 


\section{Incentives for human capital investment}

The most difficult to measure - but theoretically likely benefit - may be an increase in the incentive for natives to invest in their own human capital. This can occur in theory through three mechanisms: ${ }^{5}$ i) through an increase in the domestic return to skills due to the relative scarcity created by the "brain drain"; $i i)$ through an increase in the expected value of an individual's human capital investment if they have migration as an option; and iii) through a reduction in the risk associated with the return on individual human capital investment if migration serves as a labor market stabilizer.

The first effect is the improvement of labor market conditions for highly skilled workers when their domestic supply is reduced by emigration to other national labor markets. Wages and unemployment for high-skilled workers in less-developed countries (with less developed financial markets and entrepreneurial infrastructure) may be particularly sensitive to "over-supply". Other channels, through which migration leads to increased supply may, of course offset this.

The second effect results from uncertainties that individuals might have about their likely migration behavior. To show this in a simple algebraic form, the expected value of an individual's human capital can be expressed as:

Aspects of the immigrant labour force are picked from different data systems, but many data gaps remain.

5. The domestic demand for skilled labour, and hence the return on human capital, may also increase due to other effects, discussed later in this chapter, which might lead to increased R\&D in sending countries. Although many of these hypothesised effects clearly are interrelated, this chapter does not attempt to theorise beyond partial equilibrium effects. 


$$
E(H)=P_{m} E_{f}(H)+\left(1-P_{m}\right) E_{d}(H)
$$

where $\mathbf{P}_{\mathbf{m}}$ is the subjective individual probability of migration, $\mathbf{E}_{\mathbf{f}}$ is the expected value of human capital $\mathbf{H}$ in the best foreign labor market, and $\mathbf{E}_{\mathbf{d}}$ is the expected value of the same human capital in the domestic labor market. Where the expected foreign value of human capital is much greater than the domestic value, even a small non-zero expectation of migration may have an important effect on the expected value of a human capital investment decision. ${ }^{6}$

The third effect depends upon whether the amount of emigration of high-skilled labor from a country is related to current labor market conditions. If a downturn in demand for high-skilled labor in a country results in more high-skilled workers leaving, that might tend to reduce fluctuations in employment and salaries, reducing the "risk" associated with the human capital investment. The considerable investments required for an individual to acquire higher skills might seem less worthwhile if the labor market demand for those skills is volatile. ${ }^{7}$ To some extent, this role of a labor market stabilizer may be offset by any instability caused by return migration driven by changes in conditions in the receiving countries. ${ }^{8}$

6. In a further straining of the "brain drain" metaphor, an Indian engineer, commenting on the Cable News Network about the disparity between degree production and opportunities in India, said, "Better a brain drain than brains down the drain".

7. To the extent that high-skilled also means specialised skills, additional training may make individuals more, rather than less, sensitive to economic fluctuations. An example from the United States may be aerospace engineers, who have faced greater employment volatility than those in other occupations.

8. A prominent example of labour market instability being caused by return migration involved not high-skilled, but low-skilled labour - the return migration of workers from South-East Asia from the Arabian peninsula at the time of the Gulf War. 


\section{Knowledge flows and collaborations}

International migrants (other than refugees) seldom break all ties with their country of origin. There is reason to believe that high-skilled migrants who have extensive education and, often, work experience in their country of origin maintain contacts with former colleague and education institutions. This may provide a benefit for sending nations by facilitating the formation of international networks of contact and knowledge exchange - both with expatriate natives and with contacts nurtured by returning expatriates while abroad. Some evidence for this is seen in Figure 1, which show a positive 0.61 correlation between the $\log$ of the number of US doctorates received by natives of a country and percentage of that country's internationally coauthored articles with the United States.9

The fact that contact in graduate school may lead to research collaboration across borders is not an unexpected effect. The same effect is likely to be created by the international movements of people employed by industries. Movement of workers between firms has long been recognized as a powerful source of knowledge transfer both of technology and of more subtle things such as business practices and networks of contacts - and this is likely to occur even when the firms are across national borders.

9. This is determined by the location of the institution that each co-author is affiliated with. Thus, it could be between natives of the same country, one of whom works in the United States, or any other combinations of nativities. 
Figure 1. Scatter plot of percentage of 1991-95 multinational papers with a US author vs. number of 1986-90 US science and engineering PhDs received by natives of a country

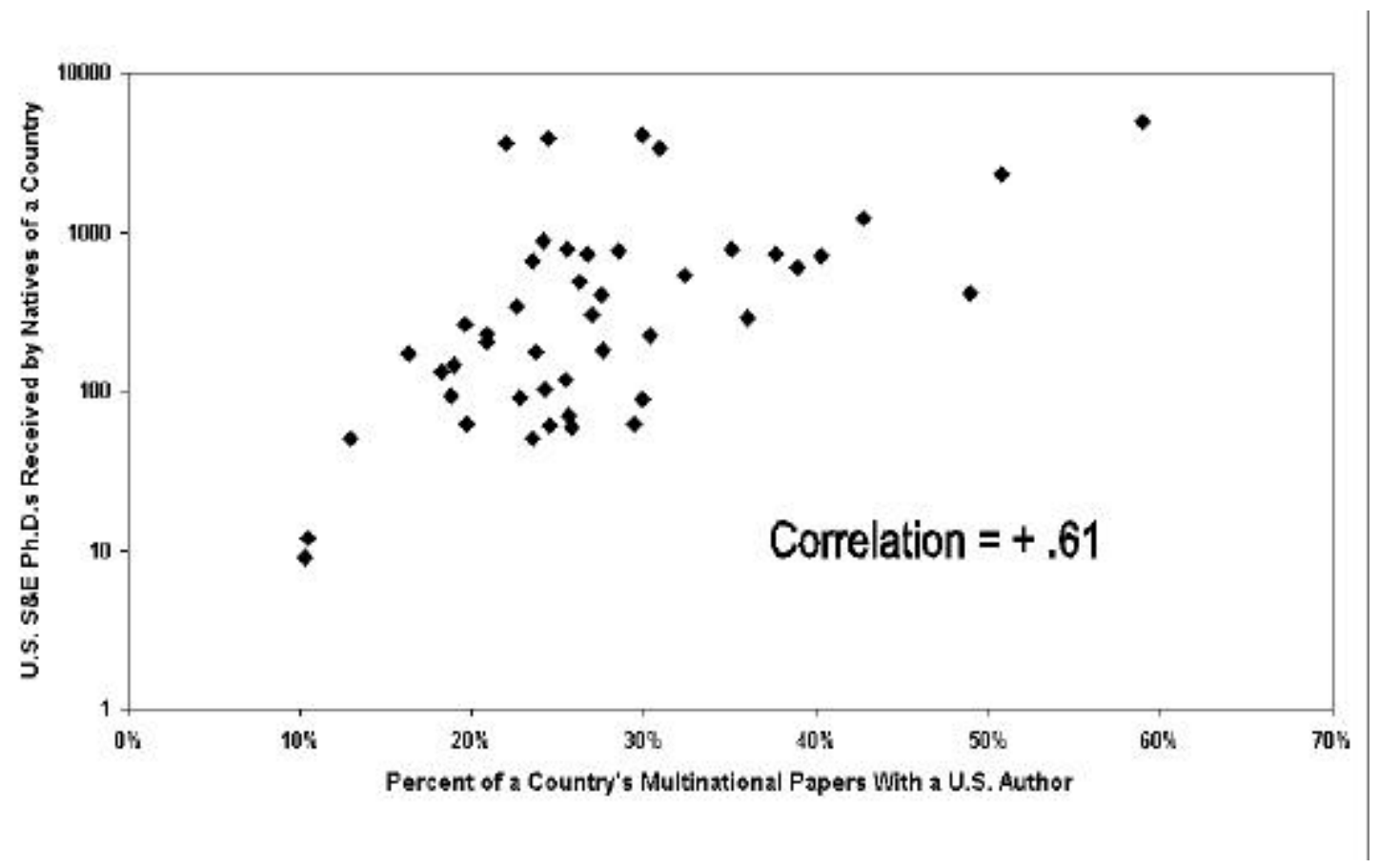

Return of natives with foreign education and human capital

An important, but not necessary, way for a sending country to benefit from knowledge flows is for its natives to return after spending a period of time outside their country of origin. Despite wage differentials and other differences in opportunities, return migrations are common even between developed and lessdeveloped countries. ${ }^{10}$ To a great extent, this is unsurprising and reflects the importance of cultural and family ties to migrants. Another factor which encourages return migration is the temporary nature of the work permits that many countries use as their primary method of allowing employers to recruit non-citizens. For example, in the United States, the most common high-skilled work visa (known as a H-1b) is for 
three years, with a single three-year renewal allowed, and is not formally ${ }^{11}$ part of any path to a permanent visa.

Finn (1999) shows that around half of foreign students with temporary visas who receive US science and engineering doctorates are still working in the United States five years later, this implies that the other half leave the United States ${ }^{12}$ with training received at a US university and perhaps a postdoc or other post-graduate work experience. As shown in Table 3, Finn found that "stay" rates varied by field of degree, ranging from $32 \%$ in the social sciences to $61 \%$ in the physical sciences and mathematics.

10. See Abowd and Robinson (1994) for a profile of general emigration rates from the United States.

11. No good estimates of $\mathrm{H}-1 \mathrm{~b}$ visa holders remaining in the United States are available.

12. This does not necessarily mean a return to their country of origin. 
Table 3. 1992-93 temporary visa US PhD recipients remaining in the United States, 1994-97 Percentages

\begin{tabular}{|c|c|c|c|c|}
\hline & 1994 & 1995 & 1996 & 1997 \\
\hline All S\&E PhD recipients & 48 & 51 & 52 & 53 \\
\hline $\begin{array}{l}\text { Physical sciences and } \\
\text { mathematics }\end{array}$ & 55 & 59 & 60 & 61 \\
\hline Life sciences & 48 & 51 & 53 & 54 \\
\hline Social sciences & 29 & 31 & 32 & 32 \\
\hline Engineering & 49 & 53 & 53 & 54 \\
\hline
\end{tabular}

Source: Finn (1999).

Also noteworthy is that the stay rates shown in Table 3 hold steady or increase somewhat with time since degree. However, another data source, the NSF's Survey of Doctorate Recipients (SDR), suggests that even those who do stay in the United States leave after a period of time. This seeming contradiction may be reconciled through a complex pattern of migration - while some individuals who earned a US doctorate leave each year, others return.13

In 1995, a special effort was made in collecting data for the SDR to discover if survey non-respondents resided outside the United States. Since it is quite possible that other non-respondents whose location was never discovered, also resided outside the United States, this should be considered a lower-bound estimate. Table 4 presents these estimates for foreign-born individuals in the SDR (which covers those with doctorates from US schools who were either a US citizen, a US permanent resident, or

13. Finn matches Social Security numbers from the Survey of Earned Doctorates to individual earnings records. In order to protect confidentiality, the Social Security Administration reports back to Finn the percentage of a $\mathrm{PhD}$ cohort that was found in their records, and does not provide information on any individual. Thus we do not know directly if the same individuals are present each year. 
had plans to stay in the United States at the time of their degree). Thus, the SDR included only those foreign-born $\mathrm{PhD}$ recipients with particularly strong ties to the United States. Among this group, about one-fifth of those who graduated in the last three decades were identified as residing abroad; in the case of graduates from the last ten years, over $4 \%$ had moved from the United States in the previous two years.

In addition to knowledge transfers, the return of natives to a sending country also brings a gain of human capital that may not have been developed had the migrants stayed in their home countries. There are several reasons for this. Differences in the availability or quality of particular areas of university instruction may have been a reason for the original cross-border movement. Knowledge of unique technologies may also be gained in formal employment. In addition, foreign employers and educational institutions often finance both formal education and job-related training to a considerable extent.

Table 4. Lower-bound estimates of foreign-born with US science and engineering PhDs working outside the United States in 1995

US citizens, permanent residents or those who expressed definite plans to stay at time of degree

\begin{tabular}{lll}
\hline Decade of PhD & $\begin{array}{l}\text { Percentage residing outside the } \\
\text { United States in 1995 }\end{array}$ & $\begin{array}{l}\text { Percentage in 1995 who had } \\
\text { left the United States since } \\
1993\end{array}$ \\
\hline $1945-54$ & 6.1 & 0.6 \\
$1955-64$ & 13.7 & 0.8 \\
$1965-74$ & 22.7 & 1.3 \\
$1975-84$ & 22.2 & 2.3 \\
$1985-94$ & 19.4 & 4.1 \\
\hline
\end{tabular}

Source: NSF/SRS 1993, 1995 Survey of Doctorate Recipients. 


\section{Support from diaspora networks}

In the general immigration literature, many studies have analyzed the effects of having large populations of natives outside of a country's border. These include both the creation of new export opportunities for their home countries and the value of remittances to relatives and institutions in their home countries. It seems plausible that high-skilled migrants create the same type of opportunities, albeit sometimes in different ways.

Less-skilled migrants often form part of the retail and wholesale infrastructure in their new countries. High-skilled migrants may be less likely to become retail or wholesale managers, but more likely to be involved in the purchase or selection of technology products and services. For example, there is significant anecdotal evidence that Indian migrants have played a key role in the business partnerships and relationships between US and Indian technology firms.

Remittances from high-skilled migrants may also be only a variation of the phenomenon discussed in the general immigration literature. High-skilled migrants are smaller in number, but often earn higher incomes. In addition to gifts to relatives, high-skilled migrants may serve a significant financial and other role as alumni of education institutions in their home countries.

\section{Negative effects for receiving countries}

Many participants in discussions of immigration policy have been surprised in recent years to find that high-skilled international migration is no less politically 
controversial within receiving countries than is immigration in general. There is a very large literature in economics seeking to find the effect of lower-skilled immigrants on opportunities for lower-skilled natives. ${ }^{14}$ However, little research has been conducted on the effects of higher-skilled migration. Nevertheless, several effects can be hypothesized.

\section{Decreased incentive for natives to seek higher skills}

If high-skilled migrants are substitutes for natives in the domestic labor market, then a normal type of static supply and demand analysis would suggest a reduction in the wages associated with higher-skilled occupations. ${ }^{15}$ This in turn would lead to a decreased incentive by natives to make human capital investments.

There are a number of theoretical factors that may moderate any such effect on native human capital investment patterns. First, the same analyses that assume lowerskilled migrants to be substitutes for both lower-skilled natives and for capital also assume that high-skilled migrants are complements to both lower-skilled workers and to capital. Thus, high-skilled migrants might do more to create new capital investment and utilization of a perhaps underused segment of the labor force. This is to say that,

14. For a good summary of this literature, see Friedberg and Hunt (1999).

15. As in many policy debates, there is often a lack of symmetry in the arguments made. For example, economic critics of lower-skilled immigration often worry that lower-skilled immigrants act as substitutes in the labour market for lower-skilled natives, while complementing the labour of higher-skilled natives - thus making the rich richer, and the poor poorer. At the same time, there is concern that if high-skilled immigrants are substitutes for high-skilled natives, this would reduce the incentive for natives to invest in human capital. If you accepted each proposition, it would then be possible to make the dual argument - that 
to some extent, higher-skilled workers may produce economic changes that increase the demand for their services, and thus mitigate the effect of increased supply upon compensation.

Although there have been no detailed econometric studies, the most basic statistics suggest that high-skilled migration is most prevalent in fields which present relatively good employment opportunities. This may be for many different reasons. Workers may be less willing to undertake the costs of migration unless the opportunities are great. Employers may not want to pay the oftenconsiderable legal costs associated with obtaining work visas unless they face a tight domestic labor market. In addition, it has been suggested that the influx of diverse human capital brought by migrants may contribute to creating opportunities in a field.

Figures 2 and 3 compare the proportion of US science and engineering $\mathrm{PhD}$ holders who are foreign born in a list of major S\&E fields of degree to measures of labor market conditions for recent $\mathrm{PhD}$ recipients in those fields. ${ }^{16}$

Figure 2. 1988-92 science and engineering PhDs

Comparison of percentage foreign-born to median native salary for selected fields

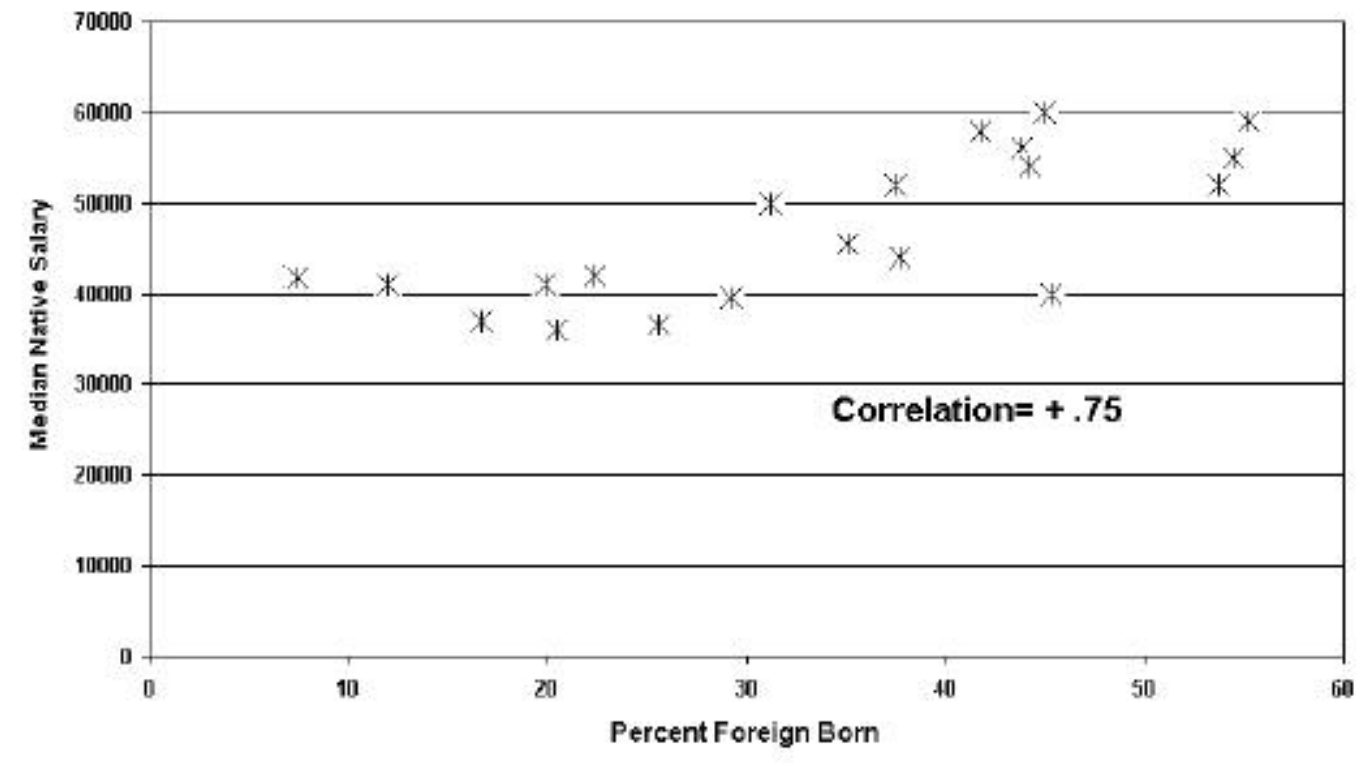

lower-skilled migrants would increase the incentive for natives to invest in human capital and that high-skilled migrants reduce income inequality.

16. Both measures were derived from the NSF/SRS 1993 Survey of Doctorate Recipients. 
Figure 3. 1988-92 science and engineering PhDs in 1993

Comparison of percentage foreign-born to percentage involuntarily out-of-field for selected fields of degree

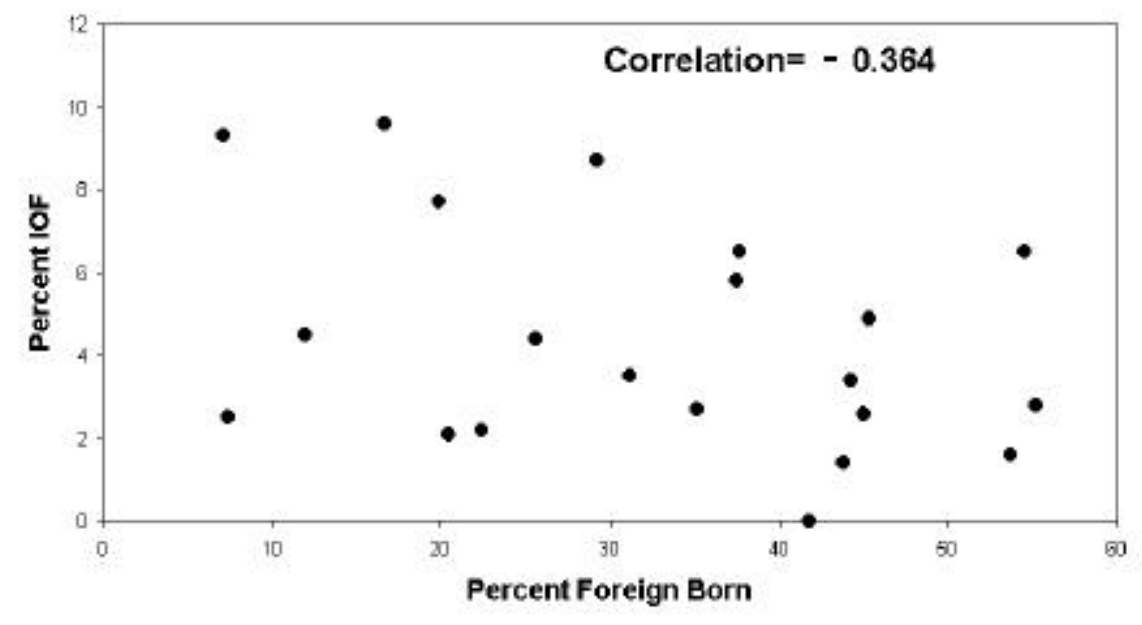

In general, the higher the proportion of foreign-born, the higher the salary. This is not driven just by the high proportion of foreign-born among US PhDs in engineering, since even in many broad fields higher foreign-born representation is associated with higher salaries: In the social sciences, economists are paid more than sociologists. In the life sciences, biological scientists are paid more than agricultural scientists. In the physical sciences, physicists are paid more than geologists. In each case, the lowerpaid field had fewer foreign-born $\mathrm{PhD}$ holders. In Figure 2, the correlation between median salary and percentage of foreign-born is a strong positive .75 .

The same pattern holds when comparing the percentage of a recent $\mathrm{PhD}$ cohort that is foreign born with a measure of labor market distress. For high-skilled workers, the unemployment rate can be a poor measure of labor market conditions in a field, since high-skilled workers are usually highly employable in some capacity. A statistic generated from the NSF SESTAT data file, the percentage involuntarily working 
outside their field of degree, often provides a more sensitive indicator of labor market conditions. Figure 3 shows the involuntary out-of-field rate for recent $\mathrm{PhDs}$ to be inversely related (-.364) with the percentage of foreign born.

\section{Crowding out of natives from advanced education}

Another, often discussed but little studied, possible effect of high-skilled migration on receiving countries is a "crowding out" of natives from graduate programs and other sources of advanced training. To some extent, this argument is simple to understand: if a given university has a limited number of openings for graduate students, then a migrant student would prevent a native from taking that slot.

The number of graduate departments that have some flexibility in the number of students they admit may offset this argument, at least in terms of aggregate positions in graduate programs. Beyond the top tier of institutions, some graduate programs would prefer to admit more high-quality graduate students to help faculty with both teaching and research. This is particularly true for graduate programs that may have trouble justifying their existence in terms of total graduate enrolment.

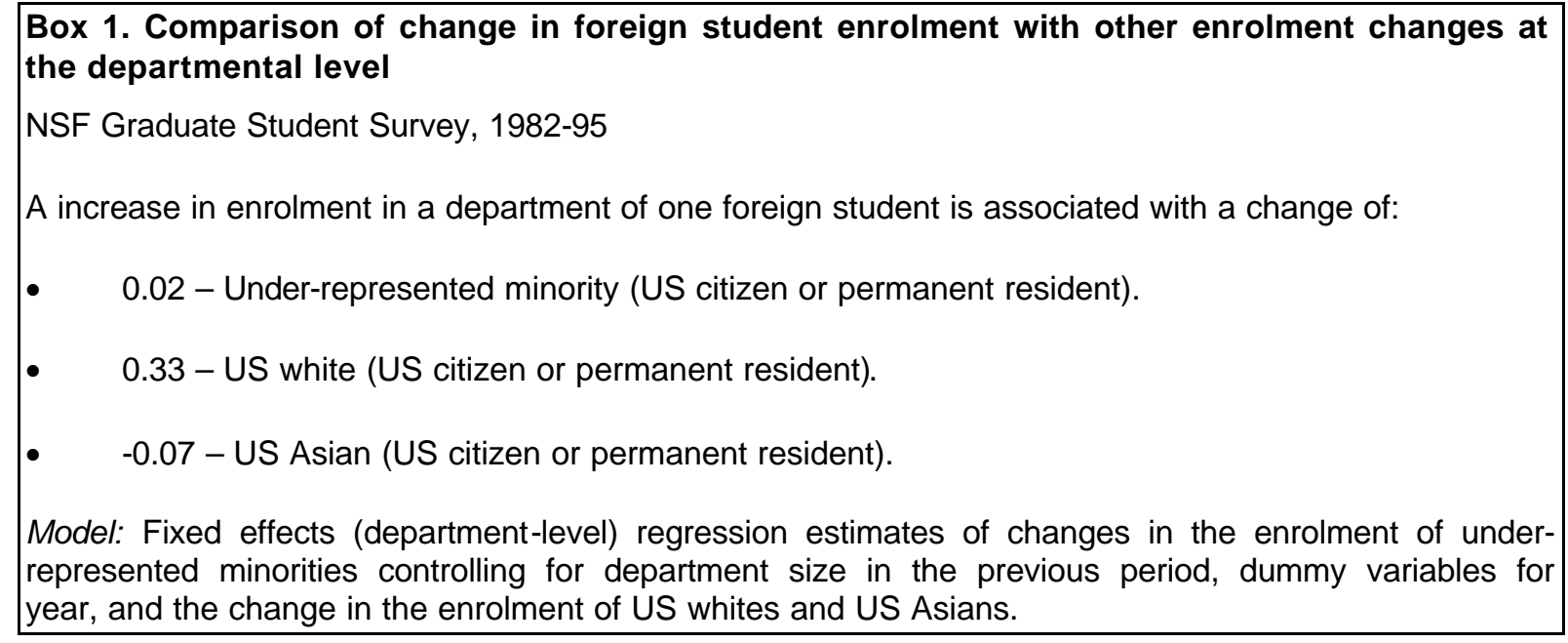


One attempt to look at the issue of displacement can be made using the National Science Foundation's Survey of Graduate Students and Postdocs (GSS). This is an annual survey of graduate departments of science and engineering to tabulate their enrolment. Using GSS records from 1982-95, it is possible to create pooled longitudinal $^{17}$ file with academic departments as the unit of observation. From this file, it is possible to make empirical estimates of the observed effect of changes in foreign student enrolment on the enrolment of various ethnic categories of US citizen and permanent resident enrolment. As summarized in Box 1, an increase in enrolment of 1.0 foreign student was associated with a increase enrolment of $1 / 3(0.33)$ of a white US student, of an additional 0.02 US under-represented minority students, and a decrease of 0.07 US Asian students. With the exception of the odd, if small, decrease for US Asians, increases in the enrolment of one group was associated with increases in the enrolment of all groups - a result inconsistent with displacement.

\section{Other negative effects}

Two other possible negative effects of high-skilled migration for receiving nations are included here for the sake of thoroughness, although even less analysis has been done on these topics than in other areas.

Some critics of high-skilled migration have raised concerns about cultural differences between natives and migrants as a barrier to native participation in

17. Econometricians have conducted considerable work on methods to analyse pooled crosssectional data of this nature. In this case, a "fixed effects" regression was performed that held constant over time department-specific effects, but similar results were found using random effects and simple OLS models. 
technology. This criticism can range from concerns about the ability of native students to understand the accents of foreign-born teachers, to workplace discrimination against natives who are not part of the same ethnic group as their boss. Although this concern is difficult to evaluate, it would be a mistake to assume that this is not an important part of the political response in many countries to high-skilled migration.

Technology transfer to potentially hostile countries is another issue which is difficult to analyze. In terms of a general transfer of knowledge that is useful to both civilian and military industries, this almost certainly occurs. In the more specific sense of espionage to obtain classified information on military technologies, it may be a murkier picture. In the context of the United States, major public espionage cases have sometimes involved ethnic affinity, ${ }^{18}$ but in other cases have involved natives apparently motivated by money, power or ideology.

\section{Positive effects for receiving countries}

Many of the positive effects of high-skilled migration for receiving countries have been discussed in the discussion of positive effects for sending countries - gains related to increases in international collaboration and technology transfers, with the same implications for increasing domestic productivity and developing global markets.

18. In at least one case, a US native, not a migrant, held the ethnic affinity that may have been a contributory motive for espionage. 
Increased economic activity and $R \& D$

Even in a model of high-skilled migration where there is no "brain circulation", receiving nations are the recipients of a brain gain. They experience an exogenous increase in their stock of human capital, often including scarce or unique sets of skills that are needed to overcome bottlenecks in production or research.

In the United States, high-skilled foreign-born workers make up a large part of the total science and engineering labor force (Table 6): one-quarter of S\&E doctorate holders; one-fifth of those holding any level of degree in engineering, computer science, chemistry, or physics; around half of $\mathrm{PhD}$ holders in computer science, electrical engineering, industrial and civil engineering.

These estimates, and others shown in Table 6 from the NSF SESTAT data file, are underestimates of the total proportion of foreign-born scientists in the United States. Because of the practical difficulties involved in tracking high-skilled migrants, SESTAT data on the US S\&E labor force exclude individuals whose science and engineering degrees were obtained from foreign educational institutions unless they were in the United States as of the decennial census of 1990. This would exclude, for example, the majority of individuals entering the United States with the high-skilled $\mathrm{H}-1 \mathrm{~b}$ temporary visa. The US Immigration and Naturalization Service reports that $60 \%$ of $\mathrm{H}-1 \mathrm{~b}$ visa recipients are holders of foreign degrees. 
Table 6. Share of foreign-born S\&E-trained US scientists and engineers, by field of highest degree and degree level, 1997

\begin{tabular}{|c|c|c|c|c|}
\hline Field of highest degree & Labor force (total) & Bachelor's degree & Master's degree & Doctorate \\
\hline All S\&E & 12.7 & 9.7 & 19.2 & 26.1 \\
\hline Engineering & 19.8 & 14.9 & 30.1 & 44.0 \\
\hline $\begin{array}{r}\text { Aerospace } \\
\text { engineering }\end{array}$ & 12.4 & 10.0 & 14.3 & 37.2 \\
\hline Chemical engineering & 21.4 & 15.8 & 35.6 & 40.1 \\
\hline Civil engineering & 21.2 & 16.5 & 33.8 & 52.0 \\
\hline Electrical engineering & 22.7 & 18.0 & 32.2 & 46.8 \\
\hline Industrial engineering & 16.9 & 11.2 & 32.3 & 50.9 \\
\hline $\begin{array}{l}\text { Mechanical } \\
\text { engineering }\end{array}$ & 17.8 & 13.5 & 32.7 & 45.4 \\
\hline Other engineering & 17.4 & 10.8 & 23.1 & 40.3 \\
\hline Life sciences & 10.7 & 7.8 & 12.8 & 24.7 \\
\hline Agriculture & 6.9 & 4.3 & 14.4 & 21.7 \\
\hline Biological sciences & 12.3 & 9.3 & 13.0 & 25.5 \\
\hline Computer/math & 16.5 & 12.7 & 24.6 & 35.6 \\
\hline Computer sciences & 20.4 & 15.6 & 30.8 & 49.5 \\
\hline $\begin{array}{l}\text { Mathematical } \\
\text { sciences }\end{array}$ & 11.8 & 9.4 & 14.8 & 30.7 \\
\hline Physical sciences & 16.0 & 11.8 & 17.2 & 28.5 \\
\hline Chemistry & 20.0 & 15.9 & 23.9 & 29.1 \\
\hline Geosciences & 8.0 & 5.4 & 10.2 & 19.5 \\
\hline Physics/astronomy & 18.8 & 11.8 & 18.6 & 30.8 \\
\hline $\begin{array}{l}\text { Other physical } \\
\text { sciences }\end{array}$ & 10.2 & 8.8 & 12.2 & 30.0 \\
\hline Social sciences & 7.0 & 6.1 & 9.4 & 12.7 \\
\hline Economics & 13.7 & 11.2 & 26.3 & 26.4 \\
\hline Political science & 7.0 & 6.2 & 10.3 & 15.7 \\
\hline Psychology & 5.4 & 5.1 & 5.8 & 7.2 \\
\hline Sociology/anthropology & 4.9 & 3.9 & 12.1 & 13.1 \\
\hline Other social sciences & 7.7 & 6.3 & 10.7 & 20.3 \\
\hline
\end{tabular}




\section{Knowledge flows and collaboration}

As shown in Figure 1 and discussed earlier, there are strong reasons to believe that international migration leads to increased international collaboration and transmission of knowledge. With reference to the United States, the increased connection to the rest of the world has always been a benefit of having large numbers of foreign students and large numbers of high-skilled immigrants.

This factor may become even more important as the rest of the world continues to expand it's R\&D capacity - as of 1997 , the United States' R\&D spending was down to $43 \%$ of the OECD total. ${ }^{19}$

\section{Increased enrolment in graduate programs}

This is the other side of concerns about displacement of natives in graduate programs. In the context of the United States, the availability of foreign students may allow many graduate departments to expand or maintain graduate programs. In other cases, foreign students may allow more elite programs to maintain very high standards by allowing them to choose among the best of both foreign and native applicants. To the extent that the benefits of a graduate program accrue to graduate students, this might not be an important benefit, or might even be viewed as a cost if graduate education is partially subsidized. However, graduate programs are also important sources of new research and knowledge. This may provide a benefit to receiving

19. See Science and Engineering Indicators 2000. 
countries even if foreign students were to leave immediately after graduation and form no part of later knowledge networks.

\section{Global effects}

In addition to any benefits or costs that might be viewed as accruing to particular countries sending or receiving high-skilled migrants, there are possible global effects that cannot be assigned to individual countries. These are essentially all the effects that could result in greater efficiency in the production of knowledge, and in the production of goods and services. Even if one rejects the idea that one country benefits from wealth and knowledge creation in another, this greater efficient would result in greater global sum of GDP, however distributed.

A better international flow of knowledge increases the efficiency of new knowledge production everywhere. It leads to better solutions to particular problems and a reduction of duplication in $R \& D$.

An international job market has important implications for the quality of job matches for both workers and employers. In a world where increased specialization leads to increased employer dependence on scarce or unique skill sets, it becomes clear why employers find it increasingly efficient to search across borders. At the same time, greater employment options resulting from a global labor market may allow workers to find the work most interesting to them.

There may also be a global benefit from the formation of international research and technology centers. Researchers on innovation have long noted the apparent 
benefits of geographic clustering of particular research activities. To a great extent, this specialized clustering required high-skilled international migration for staffing.

For all of these reasons, high-skilled international migration is likely to have, at the global level, a positive effect on the incentives for human capital investment. It increases the opportunities for high-skilled workers, both by providing the option of job search across borders and by encouraging the growth of new knowledge.

\section{Conclusion}

This paper has outlined major research and policy issues related to high-skilled international migration. Simple models of "brain drain" and "brain gain" do not fully capture either the complex movement of people and knowledge across borders, or the effects of this movement on knowledge creation and investments in both physical and human capital. Both sending and receiving countries have to be concerned with the potential positive and negative effects of high-skilled migration, and much research needs to be done to better understand these effects. Although this chapter does not explore policy options, it seems likely that the magnitude of various positive and negative effects are likely to be significantly affected by aspects of a country's immigration, education and technology policies. As with trade, some countries may find it desirable to compensate domestic "losers" from high-skilled migration as a way of gaining support for more open policies.

Globally, the net effect of high-skilled migration seems likely to be positive for both knowledge creation and economic growth and should result in both more efficient use of high-skilled labor and increased knowledge flows. However, even this 
assumption needs to be qualified, as little is known about the net global effects of high-skilled migration on human capital investment. 
Annex

\section{TREND DATA ON HIGH-SKILLED IMMIGRANTS IN THE UNITED STATES}

Table A1. Foreign-born managerial and professional workers in the United States, by occupation

US Census (1990) and Current Population Survey $(1995,1999)$

\begin{tabular}{clll}
\hline & 1990 & 1995 & 1999 \\
\hline Managerial and professional & 2364000 & 2953000 & 3724000 \\
Professional & 1310000 & 1708000 & 2104000 \\
Science and engineering & 387000 & -- & -- \\
\hline
\end{tabular}

Source: 1990 Census; 1995 and 1999 Current Population Survey.

Table A2. Foreign-born college graduates in the United States

US Census (1990) and Current Population Survey $(1995,1999)$

\begin{tabular}{llll}
\hline & 1990 & 1995 & 1999 \\
\hline Bachelor's degree & 1769000 & 2831000 & 3352000 \\
Advanced degree & 1350000 & 1581000 & 2042000 \\
Total & 3199000 & 4412000 & 5394000 \\
\hline
\end{tabular}

Source: 1990 Census; 1995 and 1999 Current Population Survey. 
Table A3. Foreign-born individuals with higher degrees in science and engineering

\begin{tabular}{|c|c|c|c|}
\hline & 1993 & 1995 & 1997 \\
\hline Total & 1082000 & 1122000 & 1149000 \\
\hline Bachelor's degree & 616000 & 657000 & 680000 \\
\hline Master's degree & 295000 & 300000 & 324000 \\
\hline Doctorate & 164000 & 159000 & 144000 \\
\hline \multicolumn{4}{|l|}{ Field of higher degree } \\
\hline Engineering & 408000 & 420000 & 428000 \\
\hline Life sciences & 155000 & 160000 & 162000 \\
\hline $\begin{array}{l}\text { Mathematical and computer } \\
\text { sciences }\end{array}$ & 160000 & 170000 & 184000 \\
\hline Physical sciences & 115000 & 116000 & 113000 \\
\hline Social sciences & 244000 & 256000 & 252000 \\
\hline \multicolumn{4}{|l|}{ Occupation } \\
\hline Engineering & 200000 & 199000 & 212000 \\
\hline Life sciences & 43000 & 42000 & 41000 \\
\hline $\begin{array}{l}\text { Mathematical and computer } \\
\text { sciences }\end{array}$ & 109000 & 124000 & 157000 \\
\hline Physical sciences & 45000 & 44000 & 43000 \\
\hline Social sciences & 24000 & 24000 & 25000 \\
\hline Non-S\&E occupation & 480000 & 502000 & 494000 \\
\hline
\end{tabular}

Note: Includes those with foreign degrees only if resident in the United States in April 1990. Source: NSF/SRS 1993, 1995, 1997 SESTAT Data Files. 
Table A4. US Immigration Service permanent visas issued, by S\&E occupation

\begin{tabular}{llllll}
\hline & Total & Engineers & $\begin{array}{l}\text { Natural } \\
\text { scientists }\end{array}$ & $\begin{array}{l}\text { Mathematical } \\
\text { and computer } \\
\text { scientists }\end{array}$ & $\begin{array}{l}\text { Social } \\
\text { scientists }\end{array}$ \\
\hline 1988 & 11000 & 8100 & 1200 & 1200 & 500 \\
1989 & 11800 & 8700 & 1200 & 1500 & 400 \\
1990 & 12600 & 9300 & 1200 & 1600 & 500 \\
1991 & 14100 & 10500 & 1300 & 1700 & 600 \\
1992 & 22900 & 15600 & 2800 & 3400 & 1100 \\
1993 & 23600 & 14500 & 3900 & 4200 & 1000 \\
1994 & 17200 & 10700 & 3100 & 2800 & 700 \\
1995 & 14100 & 9000 & 2400 & 2100 & 600 \\
1996 & 19400 & 11600 & 3700 & 3300 & 800 \\
1997 & 17000 & 10300 & 3500 & 2600 & 700 \\
1998 & 13500 & 7900 & 2500 & 2500 & 600 \\
\hline
\end{tabular}




\section{REFERENCES}

Ahmed, Bashir and Gregory Robinson (1994), "Estimates of Emigration of the Foreign-born Population: 1980-1990”, Population Estimates and Projections Technical Working Paper Series No. 9, Bureau of the Census, December.

Duleep, Harriet and Mark Regets (1999), "Immigrants and Human Capital Investment", American Economic Review, May.

Duleep, Harriet and Mark Regets, (1994) "The Elusive Concept of Immigrant Quality”, Discussion Paper PRIP-UI-28, Washington, DC: The Urban Institute,

Eckstein, Zvi and Yorum Weiss (1998), "The Absorption of Highly Skilled Immigrants", Tel Aviv University Working Paper No. 3-98, February.

Finn, Michael G. (1999), Stay Rates of Foreign Doctorate Recipients From U.S. Universities, Oak Ridge Institute for Science and Education.

Friedberg, Rachel and Jennifer Hunt (1999), "Immigration and the Receiving Economy", in The Handbook of International Migration, Charles Hirschman et al. (eds.), Russell Sage Foundation, New York.

Johnson, Jean and Mark Regets (1998), International Mobility of Scientists and Engineers to the United States: Brain Drain or Brain Circulation, National Science Foundation (NSF 98-316).

Kahadria, Binod (1999), The Migration of Knowledge Workers: Second-Generation Effects of India's Brain Drain, Sage Publications, New Delhi.

Levin, Sharon and Paula Stephan (1999), "Are the Foreign Born a Source of Strength for U.S. Science?”, Science 285, pp. 1213-1214.

Levine, Daniel et al. (1985), Immigration Statistics: A Story of Neglect, National Research Council, National Academy Press, Washington, DC.

Lowell, B.L. (ed.) (1999), Foreign Temporary Workers in America: Policies that Benefit America, Quorum Press, New York.

Mahroum, Sami (1999), "Highly Skilled Globetrotters: The International Migration of Human Capital", in OECD (forthcoming), Mobilising Human Resources for 
Innovation: Proceedings from the OECD Workshop on Science and Technology Labour Markets, OECD, Paris.

National Science Board (2000), Science and Engineering Indicators 2000, National Science Foundation (NSB-00-1).

Regets, Mark (1995), Immigrants are 23 Percent of U.S. Residents with S\&E Doctorates, National Science Foundation (NSF 95-339), November.

Regets, Mark (1999), "Foreign Science \& Technology Personnel in the United States: An Overview of Available Data and Basic Characteristics", in OECD (forthcoming), Mobilising Human Resources for Innovation: Proceedings from the OECD Workshop on Science and Technology Labour Markets, OECD, Paris. 


\section{IZA Discussion Papers}

No.

Author(s)

354

J. Kluve

355
J. Kluve
H. Lehmann

C. M. Schmidt

356

357
C. Heady
T. Mitrakos
P. Tsakloglou

C. Knoppik

T. Beissinger

T. Beissinger

O. Buesse

M. Pflüger

J. Hansen

M. Lofstrom

M. C. Berger

J. S. Earle

K. Z. Sabirianova
J. Angrist
V. Lavy

H. Antecol

D. A. Cobb-Clark

S. J. Trejo

M. Jäntti

S. P. Jenkins

H. S. Nielsen

M. Rosholm

N. Smith

L. Husted

Mark C. Regets
Title

Area

Date

On the Role of Counterfactuals in Inferring

6

09/01

Causal Effects of Treatments

Disentangling Treatment Effects of Polish Active

$4 / 6$

09/01

Labor Market Policies: Evidence from Matched

Samples

The Distributional Impact of Social Transfers in

3 the European Union: Evidence from the ECHP

How Rigid are Nominal Wages?

Evidence and Implications for Germany

Bismarck versus Beveridge: Which UnemployLabor Market Shocks?

A Simple, Analytically Solvable Chamberlinian Agglomeration Model

2

The Dynamics of Immigrant Welfare and Labor

$1 / 3$

09/01

Market Behavior

Worker Training in a Restructuring Economy:

4

09/01

Evidence from the Russian Transition

New Evidence on Classroom Computers and

6

09/01

Pupil Learning

Immigration Policy and the Skills of Immigrants

2

to Australia, Canada, and the United States

Examining the Impact of Macro-Economic 3 Conditions on Income Inequality

Qualifications, Discrimination, or Assimilation? 1 An Extended Framework for Analysing Immigrant Wage Gaps

Research and Policy Issues in High-Skilled

International Migration: A Perspective with Data from the United States 